\title{
Gene profiling of Toll-like receptor signalling pathways in neutrophils of patients with acute-on-chronic liver failure
}

\author{
Yi Zhang ${ }^{1,2}$, Wei Wu ${ }^{3 \dagger}$, Yijie Wang ${ }^{3 \dagger}$, Lingjia Tong ${ }^{4}$, Meng Hong ${ }^{3}$, Qi Xia ${ }^{3 *}$ [D and Zhi Chen ${ }^{3 *}$
}

\begin{abstract}
Objectives: Toll-like receptors (TLRs) on neutrophils play a crucial role in detecting pathogens and organ/tissue injury in acute-on-chronic liver failure (ACLF). However, little is known about the exact mechanisms and potential signalling pathways. The aim of this study was to investigate alterations in TLR signalling pathways in neutrophils of ACLF patients.

Methods: Twenty-seven patients with compensated cirrhosis $(n=9)$, decompensated cirrhosis $(n=9)$ and ACLF $(n=9)$ were enrolled in the study. Neutrophils were isolated, and alterations in TLR signalling pathways were evaluated using an $R T^{2}$ Profiler ${ }^{\mathrm{TM}}$ PCR Array. The fold change for each gene $\left(2\left(^{-\Delta \triangle C T}\right)\right)$ was compared among the groups. Genes with a fold change ratio of $\geq 2$ or $\leq 0.5$ along with a $p$ value of $<0.05$ were considered to be differentially expressed.
\end{abstract}

Results: A total of 17 genes were upregulated in neutrophils from patients with compensated cirrhosis and were mainly distributed in adaptors, TLR-interacting proteins and downstream pathways. Six genes were detected in patients with decompensated cirrhosis. A trend of downregulation of genes in the TLR signalling pathway was observed in neutrophils of patients with cirrhosis and ACLF. TLR3, IFNG, ILIB, TBK1, CCL2 and LTA were downregulated in neutrophils. Moreover, CD14 and IL10 were upregulated in neutrophils of ACLF patients.

Conclusions: TLR signalling pathway genes were differentially regulated in neutrophils between cirrhosis and ACLF. In ACLF patients, defective expression of TLR3 and IFN, along with enhanced CD14 and IL10 expression, was characterized by transcriptional alterations of neutrophils.

Keywords: Toll-like receptors, mRNA, Pathogens and organ/tissue injury, Acute-on-chronic liver failure, Neutrophil

\section{Introduction}

Acute-on-chronic liver failure (ACLF) is a new clinical entity defined as acute exacerbation of underlying chronic liver disease, which usually triggers multiple

*Correspondence: xiaqi@zju.edu.cn; zjuchenzhi@zju.edu.cn

tWei Wu and Yijie Wang authors contributed equally to this work

${ }^{3}$ State Key Laboratory for Diagnosis and Treatment of Infectious Diseases, Collaborative Innovation Center for Diagnosis and Treatment of Infectious

Disease, The First Affiliated Hospital, Zhejiang University School of Medicine, Hangzhou 310003, China

Full list of author information is available at the end of the article organ failure and high short-term mortality [13]. The key driver of ACLF is the burst of systemic inflammation caused by bacterial infections, acute liver injury, variceal bleeding, or other acute injuries [3]. Specifically, the severity, duration and type of systemic inflammation are reported to substantially affect the outcome of ACLF [6, 7]. To the best of our knowledge, the function of neutrophils is critical in determining the nature of systemic inflammation [27]. On this basis, it is reasonable to assume that functional modulation of the innate immune system may serve as a potential treatment option for ACLF.

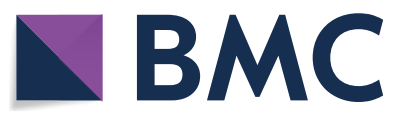

(c) The Author(s) 2021. Open Access This article is licensed under a Creative Commons Attribution 4.0 International License, which permits use, sharing, adaptation, distribution and reproduction in any medium or format, as long as you give appropriate credit to the original author(s) and the source, provide a link to the Creative Commons licence, and indicate if changes were made. The images or other third party material in this article are included in the article's Creative Commons licence, unless indicated otherwise in a credit line to the material. If material is not included in the article's Creative Commons licence and your intended use is not permitted by statutory regulation or exceeds the permitted use, you will need to obtain permission directly from the copyright holder. To view a copy of this licence, visit http://creativecommons.org/licenses/by/4.0/. The Creative Commons Public Domain Dedication waiver (http://creativecommons.org/publicdomain/zero/1.0/) applies to the data made available in this article, unless otherwise stated in a credit line to the data. 
Toll-like receptors (TLRs), probably the most important class of pattern-recognition receptors, are crucial in the regulation of the innate immune system [18]. They were first identified as key receptors in the recognition of pathogen-associated molecular patterns (PAMPs). Currently, 11 types of TLRs have been identified in humans, among which 10 are functional [18]. For example, in combination with lipopolysaccharidebinding protein and CD14, TLR4 on the surface of innate immune cells can recognize lipopolysaccharide (LPS), which is a component present in most gramnegative bacteria [21]. In addition, TLR3 located on endosomes can recognize retroviral double-stranded RNA [2]. Recently, TLRs have been shown to be involved in sterile inflammation caused by tissue damage [29]. TLRs are capable of recognizing damage-associated pattern molecules (DAMPs), which subsequently activate innate immune cells [29]. For instance, cellular HMGB1, a chromatin protein, can be recognized by TLR4 on neutrophils, leading to the formation of neutrophil extracellular traps (NETs) [14].

PAMPs and DAMPs have been detected in the serum or plasma samples of ACLF patients [9, 19]. Increased TLR expression and altered neutrophil responses were reported in ACLF patients [5, 26]. However, there is still a lack of a comprehensive understanding of TLR signalling cascades. In this study, RNA qRT-PCR array technology was utilized to evaluate the relevant expression of TLRregulated genes in neutrophils from ACLF patients. We aimed to identify the key TLR pathways that may serve as therapeutic targets for treating ACLF.

\section{Materials and methods Patients}

A total of 27 patients with compensated cirrhosis $(n=9)$, stable cirrhosis $(n=9)$ and ACLF $(n=9)$ admitted to the First Affiliated Hospital of Zhejiang University were enrolled in this study. Meanwhile, 9 matched healthy volunteers who received physical examinations during the same period served as healthy controls (HCs). Those diagnosed with ACLF based on the EASL-ACLF criteria [20] were included in this study. Patients with the following conditions were excluded from the study: those with human immunodeficiency virus infection; confirmed or suspected malignancies; pregnant women; received organ transplantation previously; received administration of immunosuppressive drugs; or those with active bacterial infection. Written consent was obtained from each patient or their legal relations. The study protocols were approved by the Ethics Committee of the First Affiliated Hospital of Zhejiang University and complied with the Helsinki Declaration.

\section{Isolation of neutrophils}

Peripheral venous blood samples were collected within $24 \mathrm{~h}$ upon admission. Neutrophils were isolated from whole blood samples using a Polymorph prep kit (AxisShield PoC AS, Norway) according to the manufacturer's instructions. Cells were resuspended in $1 \mathrm{ml}$ TRIzol reagent (Invitrogen, CA, USA), followed by storage in liquid nitrogen.

\section{RNA extraction, CDNA and PCR array}

An $\mathrm{RT}^{2}$ Profiler $^{\mathrm{TM}}$ PCR Array for Human TLR Signalling Pathway (PAHS-018Z, QIAGEN) was used in this section. RNA extraction, cDNA synthesis and PCR array preparation were performed according to the manufacturer's instructions. Briefly, the experimental RNA samples were converted into first-strand cDNA using an $\mathrm{RT}^{2}$ first-strand kit (QIAGEN). Afterwards, the cDNA was mixed with an appropriate $\mathrm{RT}^{2}$ SYBR Green Mastermix (QIAGEN). The mixture was aliquoted into the wells of an $\mathrm{RT}^{2}$ Profiler PCR Array. The amplification results were expressed as $\mathrm{Ct}$ and normalized to the housekeeping gene $18 \mathrm{~S}$ rRNA $\left({ }^{\Delta C T}\right)$. The fold change of gene expression was calculated as $2\left(^{-\Delta \Delta \mathrm{CT}}\right)$.

\section{TLR signalling pathway mapping}

Kyoto Encyclopedia of Genes and Genomes (KEGG) Mapper was used to analyse differentially expressed genes $^{16}$. The ratio mean of gene expression was calculated in the control and ACLF groups, which was visualized in a colour code in the TLR signalling pathway (KEGG hsa04620).

\section{Statistical analysis}

All data were analysed using SPSS 16.0 software (SPSS, Chicago, IL) and R 4.0.3. Student's t-test, Mann-Whitney U-test or Chi square test was utilized for the data comparison among groups. A two-sided P value of $<0.05$ was considered to be statistically significant. PCA was performed by ggbiplot $\mathrm{R}$ package. Volcano plots were plotted by ggplot2 $\mathrm{R}$ package.

\section{Results}

\section{Patient' characteristics}

As shown in Table 1, age and sex were matched among the $\mathrm{HC}$, compensated cirrhosis and stable cirrhosis groups; however, they were not matched among the ACLF patients. As expected, compared to other groups, ACLF patients had severe hepatic dysfunction, jaundice 
Table 1 Demographic and clinical characteristics of the study participants

\begin{tabular}{|c|c|c|c|c|}
\hline Variables & $\begin{array}{l}\text { Health controls } \\
(n=9)\end{array}$ & $\begin{array}{l}\text { Compensated cirrhosis } \\
(n=9)\end{array}$ & $\begin{array}{l}\text { De-compensated cirrhosis } \\
(\mathrm{n}=9)\end{array}$ & $\begin{array}{l}\text { ACLF } \\
(n=9)\end{array}$ \\
\hline Male/female & $6 / 3$ & $5 / 4$ & $6 / 3$ & $6 / 3$ \\
\hline Age & $53.4 \pm 3.7$ & $54.4 \pm 6.7$ & $58.3 \pm 12.4$ & $47.3 \pm 10.9$ \\
\hline \multicolumn{5}{|l|}{ Aetiologies of cirrhosis } \\
\hline HBV & 0 & 7 & 6 & 8 \\
\hline Non-HBV & 9 & 2 & 3 & 1 \\
\hline \multicolumn{5}{|c|}{ De-compensation events } \\
\hline Ascites & - & 0 & 6 & 2 \\
\hline UGH & - & 0 & 3 & 1 \\
\hline $\mathrm{HE}$ & - & 0 & 0 & 0 \\
\hline Jaundice & - & 0 & 0 & 9 \\
\hline Organ failure & - & & & \\
\hline Liver failure & - & 0 & 0 & 9 \\
\hline Coagulation failure & - & 0 & 0 & 6 \\
\hline Kidney failure & - & 0 & 0 & 0 \\
\hline Cerebral failure & - & 0 & 0 & 0 \\
\hline Circulation failure & - & 0 & 0 & 0 \\
\hline Lung failure & - & 0 & 0 & 0 \\
\hline WBC $\left(10^{9} / L\right)$ & $5.4(3.5)$ & $4.2(2.8)$ & $2.1(2.8)$ & $7.4(7.1)$ \\
\hline $\operatorname{PLT}\left(10^{9} / \mathrm{L}\right)$ & $123(24)$ & $89(111)$ & $60.5(57)$ & $109(58)$ \\
\hline TB (umol/L) & $6(3.4)$ & $14(15.5)$ & 19.5 (19.5) & $368(135.3)$ \\
\hline INR & $1(0.1)$ & $1.1(0.1)$ & $1.4(0.5)$ & $2.6(0.9)$ \\
\hline Creatinine(umol/l) & $78(22)$ & $64(20)$ & $68(12)$ & $66(30.8)$ \\
\hline Albumin(g/L) & $43(5.7)$ & $40.3(11.2)$ & $33(9.8)$ & $31.7(5.6)$ \\
\hline MELD score & - & $5.3(7.4)$ & $8.5(7)$ & $25(5)$ \\
\hline CLIF-C ACLFs & - & - & - & $41.5(8.3)$ \\
\hline
\end{tabular}

HBV hepatitis B virus, UGH upper gastrointestinal haemorrhage, HE hepatic encephalopathy, Jaundice TBil $\geq 85 \mu \mathrm{mol} / \mathrm{L}$, WBC white blood cell, $P L T$ platelet, $T B$ total bilirubin, INR: international normalized ratio, MELD model for end-stage liver disease,CLIF-C ACLFs Chronic liver failure Consortium Acute-on-chronic liver failure scores

and coagulopathy, as evidenced by laboratory measures and scores of disease severity.

\section{PCR array in polymorphonuclear neutrophils (PMNs)}

Genes of the TLR signalling pathway were differentially expressed in PMNs from compensated cirrhosis to ACLF patients compared to HCs. Patients with compensated cirrhosis represented a predominant upregulation of TLR pathway-related genes, including NFKBIA, NFKB, NFRKB, NFKBIL1, MAP4K4, TNFRSF1A, IRF1 and $E L K 1$, which were distributed in downstream pathways and target genes (i.e., MAPK8IP3, TIRAP, CD14, TOLLIP and HSPA1A) among adaptors and TLR-interacting protein genes, SIGIRR and TLR9 among TLR genes, and FADD and IRAK1 among the effector genes. Only TLR3 and PTGS2 were downregulated. Patients with decompensated cirrhosis presented a more limited alteration in TLR signalling genes, including 6 of the 17 upregulated genes observed in compensated cirrhosis, SIGIRR, IRAK1, HSPA1A, TOLLIP and ELK1, as well as downregulation of $I L-1 B$. In contrast, ACLF patients had a different type of alteration in TLR signalling genes, which was characterized by downregulation of TLR3, CXCL8, IFNG, IL1B, TBK1, CCL2 and LTA. In addition to FADD, IRAK1, CD14, HSPA1A, NFKBIL1 and ELK1 were commonly upregulated in cirrhosis; however, IL-10 was uniquely upregulated in ACLF (Table 2). The gene expression profiles in the different groups are listed in Fig. 1. Individual gene expression profiles are listed in Fig. 2. PCA showed clustering of all the samples, which was consistent with the original groupings. The results of PCA are shown in Fig. 3. Volcano plots were listed in Additional file 1: Fig. S1.

\section{TLR signalling pathway mapping}

In this section, we explored the specific TLR pathway involved in the pathogenesis of ACLF. The KEGG TLR signalling network (KEGG hsa04620) was utilized to compare the expression levels of the HC and ACLF groups (Fig. 4). TLR signalling pathway mapping showed that the TLR3 pathway was significantly downregulated in neutrophils from ACLF patients. 
Table 2 List of differentially expressed genes of TLR signalling pathways between patients and healthy controls

\begin{tabular}{|c|c|c|c|c|}
\hline \multirow[t]{3}{*}{ Gene symbol } & \multirow[t]{3}{*}{ Gene } & \multicolumn{3}{|l|}{ Neutrophils } \\
\hline & & C-LC & D-LC & ACLF \\
\hline & & $\begin{array}{l}\text { Fold change } \\
\text { P value }\end{array}$ & $\begin{array}{l}\text { Fold change } \\
\text { P value }\end{array}$ & $\begin{array}{l}\text { Fold change } \\
\text { P value }\end{array}$ \\
\hline \multirow[t]{4}{*}{ Toll like receptor } & TLR10 & - & - & - \\
\hline & $T L R 3$ & $\begin{array}{l}0.4231 \\
0.0478\end{array}$ & - & $\begin{array}{l}0.2398 \\
0.0016\end{array}$ \\
\hline & TLR9 & $\begin{array}{l}4.0564 \\
0.0009\end{array}$ & $\begin{array}{l}2.5115 \\
0.03556\end{array}$ & $\begin{array}{l}2.6805 \\
0.023\end{array}$ \\
\hline & SIGIRR & $\begin{array}{l}2.2314 \\
0.0105\end{array}$ & $\begin{array}{l}2.1148 \\
0.0447\end{array}$ & - \\
\hline \multirow[t]{3}{*}{ Effectors } & FADD & $\begin{array}{l}2.022 \\
0.0302\end{array}$ & - & $\begin{array}{l}2.2185 \\
0.0133\end{array}$ \\
\hline & IRAKI & $\begin{array}{l}5.4967 \\
0.0003\end{array}$ & $\begin{array}{l}3.3386 \\
0.0193\end{array}$ & $\begin{array}{l}3.4884 \\
0.0089\end{array}$ \\
\hline & IRAK2 & - & - & - \\
\hline \multirow[t]{5}{*}{ Interacting proteins and adaptors } & CD14 & $\begin{array}{l}2.1815 \\
0.0116\end{array}$ & - & $\begin{array}{l}2.3584 \\
0.0033\end{array}$ \\
\hline & HSPATA & $\begin{array}{l}4.0346 \\
0.0017\end{array}$ & $\begin{array}{l}2.3591 \\
0.0183\end{array}$ & $\begin{array}{l}3.7515 \\
0.0039\end{array}$ \\
\hline & MAPK8IP3 & $\begin{array}{l}2.0727 \\
0.0129\end{array}$ & - & - \\
\hline & TOLLIP & $\begin{array}{l}2.4367 \\
0.0113\end{array}$ & $\begin{array}{l}2.111 \\
0.0039\end{array}$ & - \\
\hline & TIRAP & $\begin{array}{l}2.4229 \\
0.0012\end{array}$ & - & - \\
\hline \multirow[t]{5}{*}{ Regulation of adaptive immunity } & IFNG & - & - & $\begin{array}{l}0.173 \\
0.0006\end{array}$ \\
\hline & $1 L 10$ & - & - & $\begin{array}{l}2.6697 \\
0.0249\end{array}$ \\
\hline & ILI2A & - & - & - \\
\hline & ILIB & - & $\begin{array}{l}0.4534 \\
0.0017\end{array}$ & $\begin{array}{l}0.4067 \\
0.0025\end{array}$ \\
\hline & IL2 & - & - & - \\
\hline
\end{tabular}

\section{Discussion}

TLRs are transmembrane proteins expressed in innate immune cells, especially neutrophils, and play a central role in detecting invading microbes or endogenous danger signals and initiating corresponding immune responses [18]. Ten TLRs (i.e., TLR1-TLR10) have been identified in humans, while different TLRs can recognize various ligands, including bacterial cell wall components and viral double-stranded RNA [28]. There were five housekeeping genes and 84 genes related to TLR-mediated signal transduction. These genes were divided into different groups according to their functions: TLR, adaptor and interacting proteins, effectors, regulation of the adaptive immunity group, downstream pathways and target genes. In this study, we found a stepwise downregulation of TLR3 in neutrophils from patients with cirrhosis to those with ACLF. These results were consistent with a recent study showing defective TLR3 expression in ACLF patients [4]. As previously described, TLR3 could recognize retroviral dsRNA, which then triggered the activation of the transcription factor interferon regulatory factor-3 (IRF3) in a MyD88-independent manner. This allowed the induction of IFNs [8]. Thus, defective TLR3 signalling may lead to downregulation of type I and II interferons, interferon regulatory factor TBK1 and interferon-stimulated gene (ISG) CXCL10 expression in immune cells of ACLF patients. Although TLR4 engagement also induced IFNs in immune cells [10], TLR4 signalling was not suppressed in ACLF patients. Therefore, defective TLR3 signalling may be a major contributor to the downregulation of interferons and their ISGs in ACLF patients. Along with the IFNs, genes regulating adaptive immunity, including IL-2 and IL-12A, were significantly downregulated. It has been shown that enhanced activity of type I IFN signalling pathways is associated with excessive inflammation 
Table 2 (continued)

\begin{tabular}{|c|c|c|c|c|}
\hline \multirow[t]{3}{*}{ Gene symbol } & \multirow[t]{3}{*}{ Gene } & \multicolumn{3}{|l|}{ Neutrophils } \\
\hline & & C-LC & D-LC & ACLF \\
\hline & & $\begin{array}{l}\text { Fold change } \\
P \text { value }\end{array}$ & $\begin{array}{l}\text { Fold change } \\
\text { P value }\end{array}$ & $\begin{array}{l}\text { Fold change } \\
P \text { value }\end{array}$ \\
\hline \multicolumn{5}{|l|}{ Downstream pathway of toll like receptors } \\
\hline \multirow[t]{12}{*}{ NFKB signalling } & FADD & $\begin{array}{l}2.022 \\
0.0302\end{array}$ & - & $\begin{array}{l}2.2185 \\
0.0133\end{array}$ \\
\hline & IL10 & - & - & $\begin{array}{l}2.6697 \\
0.0249\end{array}$ \\
\hline & ILIB & - & $\begin{array}{l}0.4534 \\
0.0017\end{array}$ & $\begin{array}{l}0.4067 \\
0.0025\end{array}$ \\
\hline & IRAK1 & $\begin{array}{l}5.4967 \\
0.0003\end{array}$ & $\begin{array}{l}3.3386 \\
0.0193\end{array}$ & $\begin{array}{l}3.4884 \\
0.0089\end{array}$ \\
\hline & IRAK2 & - & - & - \\
\hline & MAP4K4 & $\begin{array}{l}2.0512 \\
0.0018\end{array}$ & - & - \\
\hline & NFKB2 & $\begin{array}{l}2.2645 \\
0.0060\end{array}$ & - & - \\
\hline & NFKBIA & $\begin{array}{l}2.0441 \\
0.0170\end{array}$ & - & - \\
\hline & NFRKB & $\begin{array}{l}2.056 \\
0.0292\end{array}$ & - & - \\
\hline & TNFRSFIA & $\begin{array}{l}2.5753 \\
0.0015\end{array}$ & - & - \\
\hline & CXCL8 & - & - & $\begin{array}{l}0.0959 \\
0.0422\end{array}$ \\
\hline & LTA & - & - & $\begin{array}{l}0.489 \\
0.0157\end{array}$ \\
\hline \multirow[t]{3}{*}{ JNK/p38 signalling } & ELK1 & $\begin{array}{l}2.9532 \\
0.0012\end{array}$ & $\begin{array}{l}2.2857 \\
0.0128\end{array}$ & $\begin{array}{l}2.4822 \\
0.0054\end{array}$ \\
\hline & $\operatorname{IL} 1 B$ & - & $\begin{array}{l}0.4534 \\
0.0017\end{array}$ & $\begin{array}{l}0.4067 \\
0.0025\end{array}$ \\
\hline & MAPK8IP3 & $\begin{array}{l}2.0727 \\
0.0129\end{array}$ & - & - \\
\hline \multirow[t]{3}{*}{ JAK/STATsignalling } & CCL2 & - & - & - \\
\hline & IFNG & - & - & $\begin{array}{l}0.173 \\
0.0006\end{array}$ \\
\hline & IL2 & - & - & - \\
\hline \multirow[t]{5}{*}{ Interferon regulatory factor signalling } & CXCL10 & - & - & - \\
\hline & $|F N B|$ & - & - & - \\
\hline & IFNG & - & - & $\begin{array}{l}0.173 \\
0.0006\end{array}$ \\
\hline & IRFI & $\begin{array}{l}2.7619 \\
0.0012\end{array}$ & - & - \\
\hline & TBK1 & - & - & $\begin{array}{l}0.4399 \\
0.0013\end{array}$ \\
\hline \multirow[t]{6}{*}{ Cytokine signalling } & CCL2 & - & - & - \\
\hline & $\operatorname{IL} 1 B$ & - & $\begin{array}{l}0.4534 \\
0.0016\end{array}$ & $\begin{array}{l}0.4067 \\
0.0025\end{array}$ \\
\hline & IRAKI & $\begin{array}{l}5.4967 \\
0.0003\end{array}$ & $\begin{array}{l}3.3386 \\
0.0193\end{array}$ & $\begin{array}{l}3.4884 \\
0.0089\end{array}$ \\
\hline & IRAK2 & - & - & - \\
\hline & SIGIRR & $\begin{array}{l}2.2314 \\
0.0105\end{array}$ & $\begin{array}{l}2.1148 \\
0.0045\end{array}$ & - \\
\hline & TNFRSFIA & $\begin{array}{l}2.5753 \\
0.0015\end{array}$ & - & - \\
\hline
\end{tabular}


Table 2 (continued)

\begin{tabular}{lllll}
\hline Gene symbol & Gene & Neutrophils & & \\
\cline { 3 - 4 } & & C-LC & D-LC & $\begin{array}{l}\text { ACLF } \\
\text { Fold change } \\
\text { P value }\end{array}$ \\
\hline NF/IL6 pathway & & $\begin{array}{l}\text { Fold change } \\
\text { P value }\end{array}$ & $\begin{array}{l}\text { Fold change } \\
\text { P value }\end{array}$ & 0.1811 \\
& & 0.4895 & -0.002 \\
\hline
\end{tabular}

C-LC compensated liver cirrhosis, D-LC decompensated liver cirrhosis, ACLF acute-on-chronic liver failure

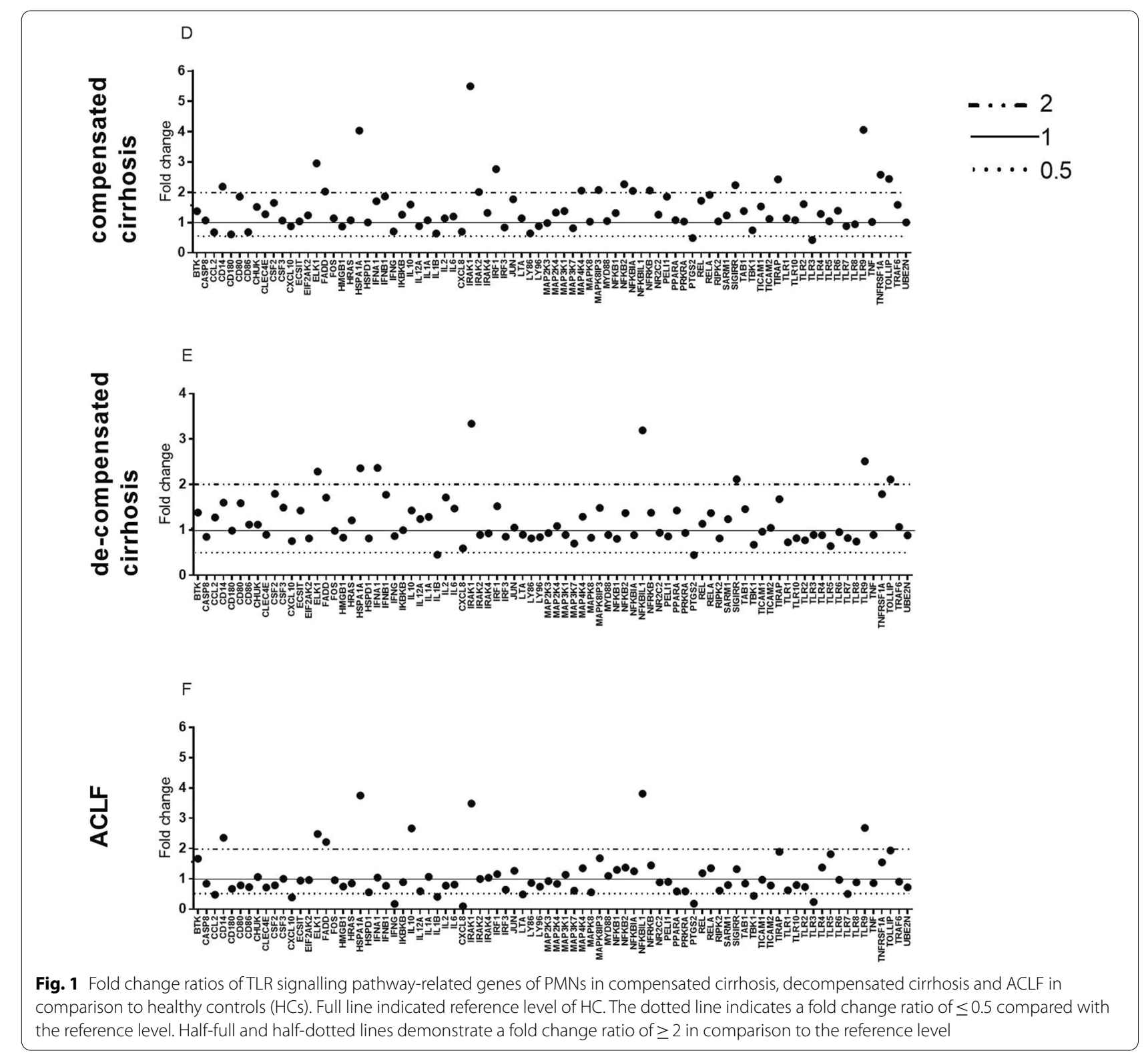

and tissue damage in mouse models of endotoxin shock [17] and autoimmune diseases [22]. Thus, downregulation of type I interferon regulatory signalling may be protective against excessive inflammation in ACLF patients. In parallel, the anti-inflammatory cytokine IL-10 was significantly upregulated in neutrophils, 


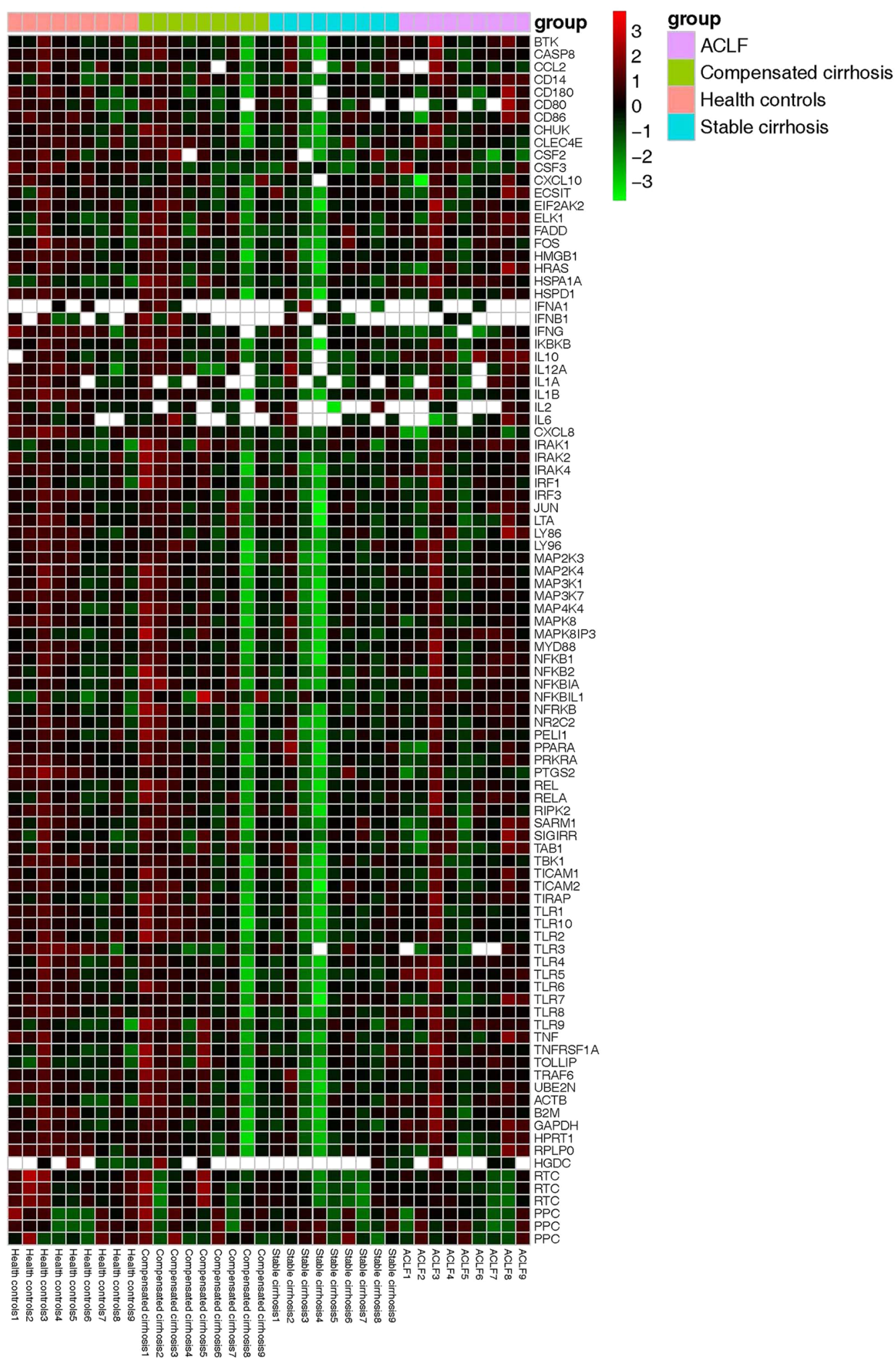

Fig. 2 Individual TLR signalling pathway-related gene expression of PMNs among the HC, compensated cirrhosis, decompensated cirrhosis and ACLF groups. The relative expression level is indicated by the colour code. Genes with significant upregulation are coloured red, and those with significant downregulation are marked green. The ubiquitous expression level was shown in black 


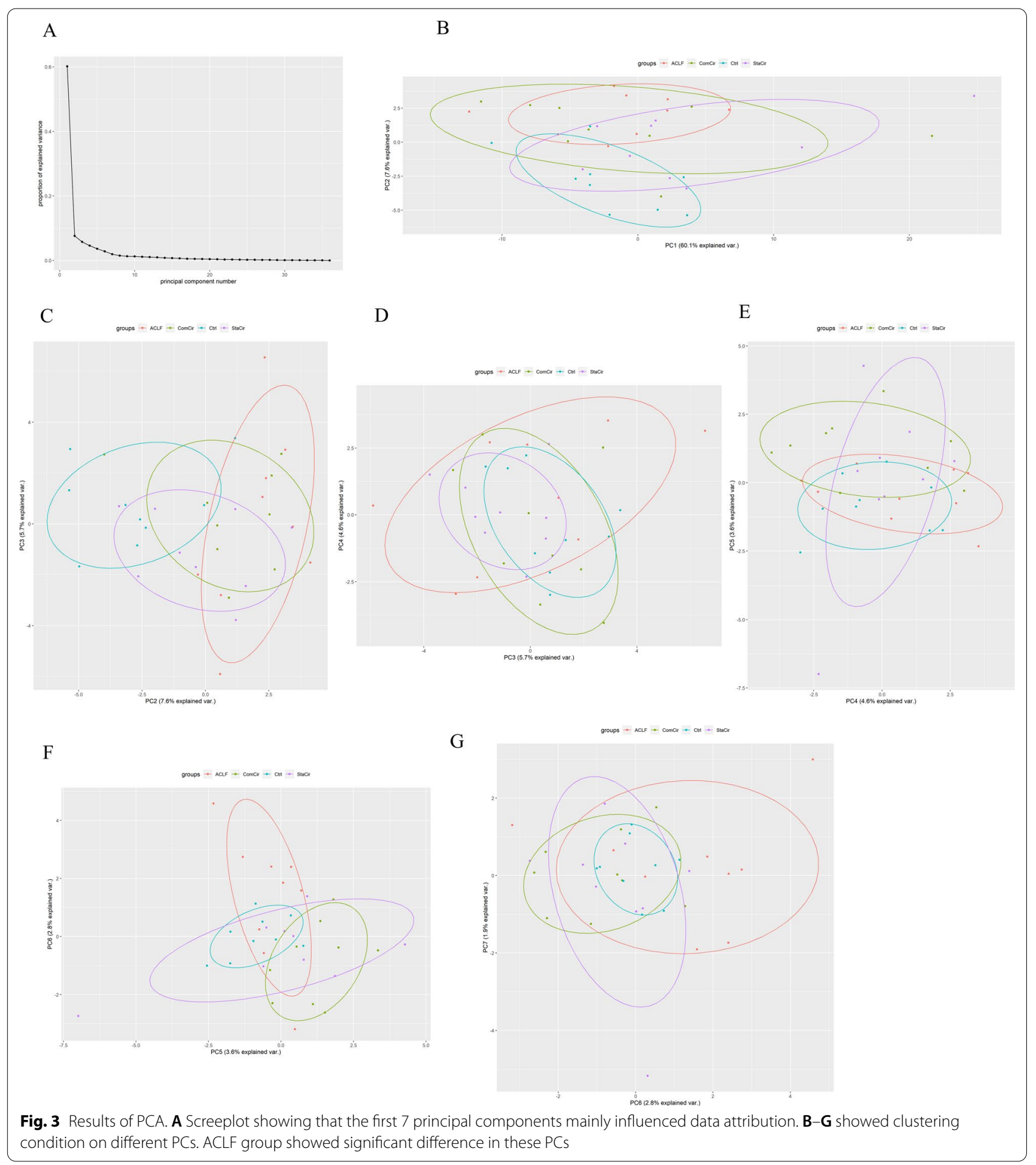

and pro-inflammatory IL-1B was downregulated specifically in neutrophils of patients with ACLF. Taken together, these findings suggested that peripheral neutrophils in ACLF patients showed defective expression of TLR3 and IFN, together with upregulation of the anti-inflammatory cytokine IL-10 at the transcriptional level.

Downregulation of IFNG was observed in all three groups, although it was not significant in the C-LC and D-LC groups, which also indicated that in chronic 


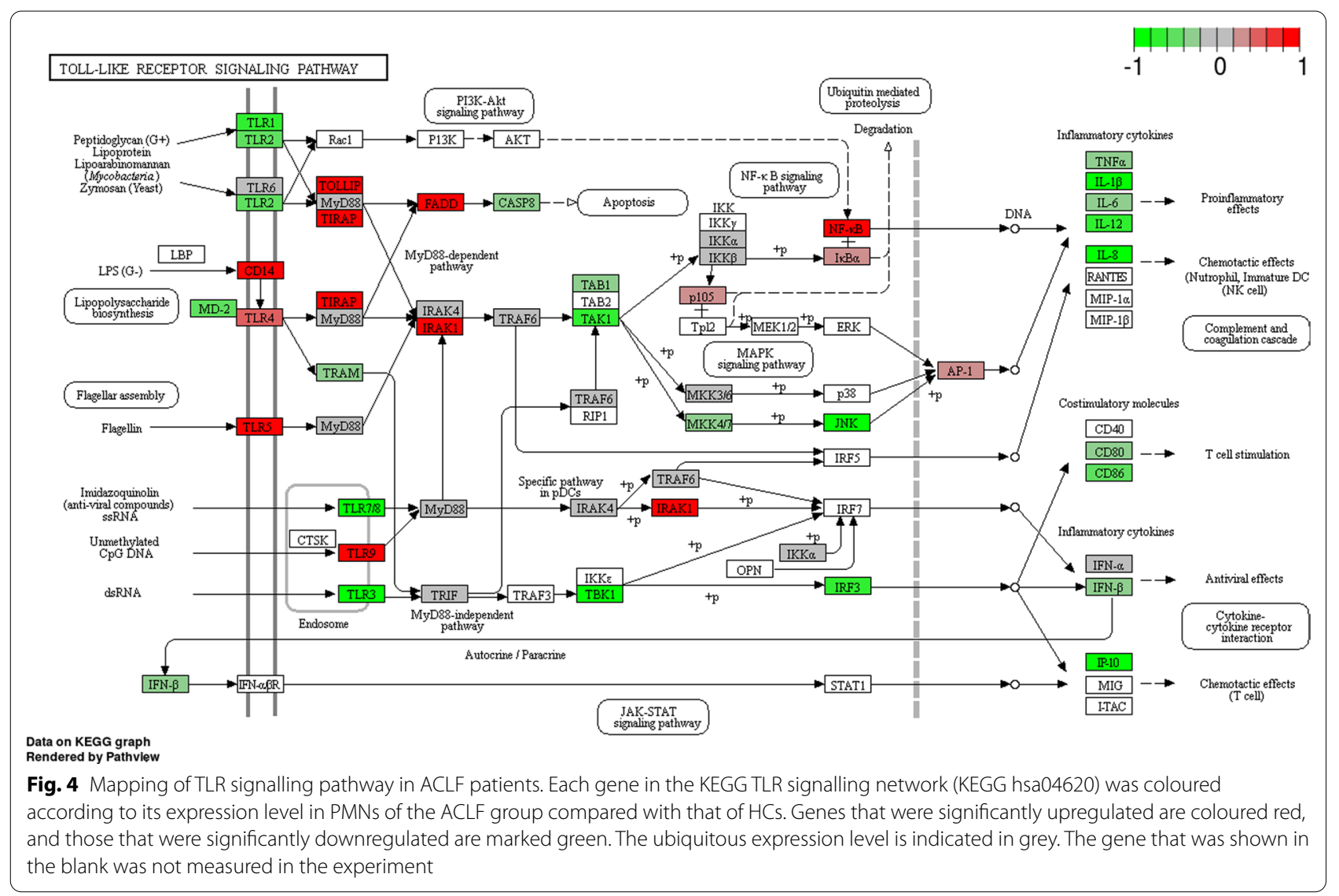

hepatic diseases, the level of immunoregulation was decreasing. IFN- reduces IL-4 production in TH1 cells [16] and plays a significant role in the class I antigen presentation pathway [24]. These results all indicated that during the development of chronic HBV-hepatitis cirrhosis, the level of immunoreaction decreased.

The TLR signalling transcriptional landscape of immune cells in ACLF was almost completely distinct from that in cirrhosis patients, which supported the clinical and experimental data that ACLF patients showed different immune dysfunctions [1]. Transcriptional alterations in immune cells may have significant clinical implications. The prevailing theory hypothesized a shift from systemic inflammatory response syndrome (SIRS) to compensatory anti-inflammatory response syndrome (CARS) during the natural history of ACLF, which led to immune paralysis and increased susceptibility to infections [15]. Indeed, several clinical studies have confirmed that ACLF patients show a higher incidence of bacterial infection than their non-ACLF counterparts [11, 23]. In human and animal studies, there was a link between impaired cellular immune function and an increased risk of bacterial infection, loss of infection control and infection-associated mortality $[4,12,25]$. Our findings revealed that a reduction in TLR signalling may impair TLR-driven neutrophil responses, which therefore represents a potential therapeutic target. A recent study demonstrated that the TLR-3 agonist poly(I:C) effectively reconstituted innate immune function in ACLF, which may serve as a promising TLR-based immunotherapy for ACLF [4].

However, there are some limitations in this study. First, there is a necessity for further verification of the PCR array results due to the limited population consistency and sample amount. Systematic studies in larger sample pools with multiple population features should be performed to provide more robust evidence. Second, considering changes in transcription and translation processes, the expression of genes could not represent the actual biological response. Thus, in vitro and animal studies are required to investigate the feasibility of crucial roles in the TLR3 signalling pathway that may serve as a target for the treatment of ACLF. Additionally, statistics are limited. There was a lack of multiple corrections of $\mathrm{p}$ values in the analysis of PCR array data. These results indicate that the study needs to be repeated and confirmed in studies with larger sample pools and through longer time periods. 
In summary, genes in the TLR signalling pathway were differentially expressed in neutrophils through different stages of cirrhosis. In addition, we identified a dysregulated key TLR pathway in the neutrophils of ACLF patients. In the future, further investigation is required to test its potential as a therapeutic target.

\section{Abbreviations}

TLR: Toll-like receptor; ACLF: Acute-on-chronic liver failure; PMN: Polymorphonuclear neutrophil; DAMPs: Damage-associated pattern molecules; HC Healthy control; C-LC: Compensated liver cirrhosis; D-LC: Decompensated liver cirrhosis.

\section{Supplementary Information}

The online version contains supplementary material available at https://doi. org/10.1186/s12967-021-03135-3.

Additional file 1: Figure S1. Volcano plots showed upregulation and downregulation of marker genes compared to the healthy control group. A. Compensated cirrhosis group compared to the healthy control. B. Decompensated cirrhosis group compared to the healthy control group. C. ACLF group compared to the health control.

\section{Acknowledgements}

We thank Dr. Lingtong Huang and Dr. Chunyun Ren for their help in data analysis.

\section{Authors' contributions}

ZY wrote the manuscript; WW and WYJ improved the data statistics and revised the manuscript; $X Q$ and $T L J$ performed the data analysis; $C Z$ and $H M$ performed the data collection. All authors have read and approved the final manuscript.

\section{Funding}

This research was funded by the National Natural Science Foundation of China (Grant Number: 81671949).

\section{Availability of data and materials}

The datasets used and/or analysed during the current study are available from the corresponding author on reasonable request.

\section{Declarations}

\section{Ethical approval and consent to participate}

This study protocol conformed to the ethical guidelines of the 1975 Declaration of Helsinki and was approved by the ethics committee of each participating hospital.

\section{Informed consent}

Informed consent was obtained from each patient included in the study.

\section{Competing interest}

The authors declare that they have no conflicts of interest.

\section{Author details}

${ }^{1}$ Department of Laboratory Medicine, The First Affiliated Hospital, College of Medicine, Zhejiang University, Hangzhou 310003, China. ${ }^{2}$ Key Laboratory of Clinical In Vitro Diagnostic Techniques of Zhejiang Province, Hangzhou 310003, China. ${ }^{3}$ State Key Laboratory for Diagnosis and Treatment of Infectious Diseases, Collaborative Innovation Center for Diagnosis and Treatment of Infectious Disease, The First Affiliated Hospital, Zhejiang University School of Medicine, Hangzhou 310003, China. ${ }^{4}$ Department of Laboratory Medicine, The Ningbo Ninth Hospital, Ningbo 315000, China.
Received: 24 May 2021 Accepted: 1 November 2021

Published online: 13 November 2021

\section{References}

1. Albillos A, Lario M, Alvarez-Mon M. Cirrhosis-associated immune dysfunction: distinctive features and clinical relevance. J Hepatol. 2014;61(6):1385-96. https://doi.org/10.1016/j.jhep.2014.08.010.

2. Alexopoulou L, Holt AC, Medzhitov R, Flavell RA. Recognition of doublestranded RNA and activation of NF-kappaB by Toll-like receptor 3. Nature. 2001;413(6857):732-8. https://doi.org/10.1038/35099560.

3. Bernardi M, Moreau R, Angeli P, Schnabl B, Arroyo V. Mechanisms of decompensation and organ failure in cirrhosis: From peripheral arterial vasodilation to systemic inflammation hypothesis. J Hepatol. 2015;63(5):1272-84. https://doi.org/10.1016/j.jhep.2015.07.004.

4. Bernsmeier C, Triantafyllou E, Brenig R, Lebosse FJ, Singanayagam A, Patel VC, et al. CD14+CD15-HLA-DR- myeloid-derived suppressor cells impair antimicrobial responses in patients with acute-on-chronic liver failure. Gut. 2017. https://doi.org/10.1136/gutjnl-2017-314184.

5. Bernsmeier C, van der Merwe S, Périanin A. Innate immune cells in cirrhosis. J Hepatol. 2020;73(1):186-201. https://doi.org/10.1016/j.jhep.2020. 03.027

6. Claria J, Arroyo V, Moreau R. The acute-on-chronic liver failure syndrome, or when the innate immune system goes astray. J Immunol. 2016;197(10):3755-61. https://doi.org/10.4049/jimmunol.1600818.

7. Claria J, Stauber RE, Coenraad MJ, Moreau R, Jalan R, Pavesi M, et al. Systemic inflammation in decompensated cirrhosis: characterization and role in acute-on-chronic liver failure. Hepatology. 2016;64(4):1249-64. https://doi.org/10.1002/hep.28740.

8. Doyle S, Vaidya S, O'Connell R, Dadgostar H, Dempsey P, Wu T, et al. IRF3 mediates a TLR3/TLR4-specific antiviral gene program. Immunity. 2002;17(3):251-63.

9. Du X, Shi Y, Yang Y, Yu Y, Lou G, Lv F, et al. DAMP molecular IL-33 augments monocytic inflammatory storm in hepatitis B-precipitated acute-onchronic liver failure. Liver Int. 2017. https://doi.org/10.1111/liv.13503.

10. Fairfax BP, Humburg P, Makino S, Naranbhai V, Wong D, Lau E, et al. Innate immune activity conditions the effect of regulatory variants upon monocyte gene expression. Science. 2014;343(6175):1246949. https://doi.org/ 10.1126/science.1246949.

11. Fernandez J, Acevedo J, Wiest R, Gustot T, Amoros A, Deulofeu C, et al. Bacterial and fungal infections in acute-on-chronic liver failure: prevalence, characteristics and impact on prognosis. Gut. 2018;67(10):1870-80. https://doi.org/10.1136/gutjnl-2017-314240.

12. Hackstein CP, Assmus LM, Welz M, Klein S, Schwandt T, Schultze J, et al. Gut microbial translocation corrupts myeloid cell function to control bacterial infection during liver cirrhosis. Gut. 2017;66(3):507-18. https:// doi.org/10.1136/gutjnl-2015-311224.

13. Hernaez R, Sola E, Moreau R, Gines P. Acute-on-chronic liver failure: an update. Gut. 2017;66(3):541-53. https://doi.org/10.1136/ gutjnl-2016-312670.

14. Huang H, Tohme S, Al-Khafaji AB, Tai S, Loughran P, Chen L, et al. Damageassociated molecular pattern-activated neutrophil extracellular trap exacerbates sterile inflammatory liver injury. Hepatology. 2015;62(2):600-14. https://doi.org/10.1002/hep.27841.

15. Jalan R, Gines P, Olson JC, Mookerjee RP, Moreau R, Garcia-Tsao G, et al. Acute-on chronic liver failure. J Hepatol. 2012. https://doi.org/10.1016/j. jhep.2012.06.026.

16. Kak G, Raza M, Tiwari T. Interferon-gamma (IFN- $\gamma$ ): exploring its implications in infectious diseases. Biomol Concepts. 2018;9(1):64-79. https:// doi.org/10.1515/bmc-2018-0007.

17. Karaghiosoff M, Steinborn R, Kovarik P, Kriegshauser G, Baccarini M, Donabauer B, et al. Central role for type I interferons and Tyk2 in lipopolysaccharide-induced endotoxin shock. Nat Immunol. 2003;4(5):471-7. https:// doi.org/10.1038/ni910.

18. Kawai T, Akira S. The role of pattern-recognition receptors in innate immunity: update on Toll-like receptors. Nat Immunol. 2010;11(5):373-84. https://doi.org/10.1038/ni.1863.

19. Michelena J, Altamirano J, Abraldes JG, Affo S, Morales-Ibanez O, Sancho-Bru P, et al. Systemic inflammatory response and serum 
lipopolysaccharide levels predict multiple organ failure and death in alcoholic hepatitis. Hepatology. 2015. https://doi.org/10.1002/hep.27779.

20. Moreau R, Jalan R, Gines P, Pavesi M, Angeli P, Cordoba J, et al. Acute-onchronic liver failure is a distinct syndrome that develops in patients with A. Gastroenterology. 2013;144(7):1426-1437 e1429. https://doi.org/10. 1053/j.gastro.2013.02.042.

21. Poltorak A, He X, Smirnova I, Liu MY, Van Huffel C, Du X, et al. Defective LPS signaling in $\mathrm{C} 3 \mathrm{H} / \mathrm{HeJ}$ and $\mathrm{C} 57 \mathrm{BL} / 10 \mathrm{SCC}$ r mice: mutations in Tlr4 gene. Science. 1998:282(5396):2085-8

22. Ronnblom $L$. The importance of the type I interferon system in autoimmunity. Clin Exp Rheumatol. 2016;34(4 Suppl 98):21-4.

23. Shi Y, Yang $Y$, Hu Y, Wu W, Yang $Q$, Zheng M, et al. Acute-on-chronic liver failure precipitated by hepatic injury is distinct from that precipitated by extrahepatic insults. Hepatology. 2015;62(1):232-42. https://doi.org/10. 1002/hep.27795[doi].

24 Schroder K, Hertzog PJ, Ravasi T, Hume D. Interferon-gamma: an overview of signals, mechanisms and functions. J Leukoc Biol. 2004;75(2):163-89. https://doi.org/10.1189/jlb.0603252.

25. Vergis N, Khamri W, Beale K, Sadiq F, Aletrari MO, Moore C, et al. Defective monocyte oxidative burst predicts infection in alcoholic hepatitis and is associated with reduced expression of NADPH oxidase. Gut. 2017;66(3):519-29. https://doi.org/10.1136/gutjnl-2015-310378.
26. Wasmuth HE, Kunz D, Yagmur E, Timmer-Stranghoner A, Vidacek D, Siewert E, et al. Patients with acute on chronic liver failure display"sepsislike" immune paralysis. J Hepatol. 2005;42(2):195-201. https://doi.org/10. 1016/j.jhep.2004.10.019.

27. Wu W, Yan H, Zhao H, Sun W, Yang Q, Sheng J, Shi Y. Characteristics of systemic inflammation in hepatitis B-precipitated ACLF: differentiate it from No-ACLF. Liver Int. 2018;38(2):248-57. https://doi.org/10.1111/liv.13504.

28. Xing $T$, Li L, Cao H, Huang J. Altered immune function of monocytes in different stages of patients with acute on chronic liver failure. Clin Exp Immunol. 2007;147(1):184-8. https://doi.org/10.1111/j.1365-2249.2006. 03259.x.

29. Zitvogel L, Kepp O, Kroemer G. Decoding cell death signals in inflammation and immunity. Cell. 2010;140(6):798-804. https://doi.org/10.1016/j. cell.2010.02.015.

\section{Publisher's Note}

Springer Nature remains neutral with regard to jurisdictional claims in published maps and institutional affiliations.
Ready to submit your research? Choose BMC and benefit from:

- fast, convenient online submission

- thorough peer review by experienced researchers in your field

- rapid publication on acceptance

- support for research data, including large and complex data types

- gold Open Access which fosters wider collaboration and increased citations

- maximum visibility for your research: over 100M website views per year

At BMC, research is always in progress.

Learn more biomedcentral.com/submissions 